\title{
RESPONSES TO WATERLOGGING AND FROST RELATED TO THE TOPOGRAPHIC SEQUENCES OF EUCALYPT SPECIES AT THREE SITES IN CENTRAL TASMANIA
}

\author{
by J.B. Kirkpatrick and N. Gibson
}

(with four tables)

KirkPATrick, J.B. \& GibSON, N., 1998 (31:xii): Responses to waterlogging and frost related to the topographic sequences of eucalypt species at three sites in central Tasmania. Pap. Proc. R. Soc. Tasm. 132: 31-34. https://doi.org/10.26749/rstpp.132.31

ISSN 0080-4703. School of Geography and Environmental Studies, University of Tasmania, GPO Box 252-78, Hobart, Tasmania, Australia 7001 (JBK); Wildlife Research Centre, CALM, PO Box 51, Wanneroo, WA, Australia 6065 (NG, formerly University of Tasmania).

The boundaries between the eucalypt species typical of flats and hollows and those typical of slopes have been commonly attributed to variable waterlogging and/or frost resistance. Seedlings from three pairs of eucalypt species from the flats and slopes at three altitudes in central Tasmania (Eucalyptus ovata, E. rubida, $500 \mathrm{~m}$; E. rodwayi, E. pauciflora, $800 \mathrm{~m}$; E. gunnii, E. coccifera, $1000 \mathrm{~m}$ ) were grown in a glasshouse experiment to test the interactive effects of species, waterlogging and fertiliser application on growth, frost resistance and frost recovery. The flats species largely proved more resistant to waterlogging, especially when fertilised, and less resistant to frost than the slopes species. Thus, it seems likely that the boundaries between the pairs of species are caused by relative frost resistance not waterlogging resistance.

Key Words: distribution, Eucalyptus, frost, nutrients, Tasmania, topography, waterlogging.

\section{INTRODUCTION}

Valley flats and hollows with few or no trees are a frequent feature of the natural landscape of southeastern Australia. In most such places, the eucalypt species occupying the flats or hollows and/or their margins differ from those occupying the adjacent slopes. Examples of the phenomenon include Eucalyptus pauciflora (slopes) and E. stellulata (flats) in the high mountains of southeastern Australia (Costin 1954), and $E$. viminalis (slopes) and E. ovata (flats) in southern Victoria and much of Tasmania (e.g. Ladiges \& Kelso 1977).

In most but not all (Parsons 1967) investigations of the relative waterlogging tolerance of Eucalyptus species, those that occur in the more waterlogged environments exhibit a lesser growth check upon the imposition of experimental inundation than those that occur in freely drained environments (e.g. Ladiges \& Kelso 1977, Blake \& Reid 1981, Guest 1982, Davidson 1985). An alternative explanation for the patterning of eucalypt species at the base of mountain slopes, at least in montane and subalpine environments, is relative frost resistance. For example, Davidson \& Reid (1987) found that E. gunnii, the species occupying the base of a frost hollow in the Snug Tiers, Tasmania, was less damaged by growing-season frost than the eucalypt species upslope. They also demonstrated interactive effects between frost and waterlogging tolerance, with Monocalyptus species having less ability to harden under waterlogging than Symphyomyrtus species.

In Tasmania, the eucalypt species that occupy the most waterlogged ground all belong to the subgenus Symphyomyrtus. The most widespread of these species is $E$. ovata, which occurs on soils of widely varying texture and fertility in the lowlands. E. perriniana and E. cordata are lowland species of waterlogged ground with much more restricted distributions (Williams \& Potts 1996). E. rodwayi is the species of waterlogged ground in the montane zone. This species has a wide edaphic range. At high altitude, the more fertile of the waterlogged soils are occupied by $E$. gunnii, while E. subcrenulata is found on the nutrient- poorer sites. A wide variety of other Symphyomyrtus and Monocalyptus species occur upslope of the waterlogged ground. Detailed maps of such distribution patterns are given in Fensham \& Kirkpatrick (1992) for areas containing flats occupied by $E$. ovata (Bothwell), E. rodwayi (Shannon) and E. gunnii (Sandbank) at low, montane and subalpine altitudes in central Tasmania. At Bothwell, E. ovata was replaced by E. viminalis (Symphyomyrtus) on the dolerite slope, and by E. rubida (Symphyomyrtus) on the mudstone slope of an alluvium-filled valley at $500 \mathrm{~m}$. At Shannon $(800 \mathrm{~m}), E$. rodwayi was replaced by $E$. pauciflora (Monocalyptus) on the slopes and, at Sandbank (1000 m), E. gunnii was replaced by E. coccifera (Monocalyptus).

The present paper reports an experiment designed to test the growth and unhardened frost, waterlogging and fertiliser application responses of E. ovata, E. rodwayi and E. gunnii and of one upslope neighbour of each of these, i.e. $E$. rubida, E. pauciflora and E. coccifera, at the sites studied by Fensham \& Kirkpatrick (1992). Our implicit hypothesis was that the species of the flats would be more tolerant of both growing-season frost and waterlogging than their upslope neighbours.

\section{METHODS}

Seed was obtained from at least five trees of each species as close as possible to one of the Bothwell, Shannon and Sandbank sites of Fensham \& Kirkpatrick (1992). Thus, seeds for $E$. ovata and $E$. rubida were obtained from near Bothwell, for E. pauciflora and E. rodwayi from nearShannon, and for E. coccifera and E. gunnii from near Sandbank. The seed for each species was mixed before germination. The germinants were transplanted into $170 \mathrm{~mm}$ diameter tubular plastic pots filled with a mixture of grey sand and peat. Ten pots of each species were allocated to each of the factorial combinations of fertiliser application and waterlogging. The pots were totally randomised within a heated glasshouse. The fertiliser treatment consisted of the application of $0.32 \mathrm{~g}$ of Aquasol (N:P:K, 23:4:18) at the recommended 
dilution $(200 \mathrm{~mL}$ water) per pot once a week. The waterlogging treatment was imposed from one month onwards and consisted of flooding to the surface of the soil. The frosting of all seedlings was undertaken after four months in a controlled temperature chamber. The roots of all seedlings were protected against frost by Sphagnum packing. The pots were randomised within the chamber to avoid results being influenced by any internal temperature gradients. Temperatures were lowered $5^{\circ} \mathrm{C}$ per hour until they attained $-5^{\circ} \mathrm{C}$. This temperature was maintained for two hours, then the seedlings were returned to the glasshouse. The methods of Ashton (1958) were used to measure leaf damage and recovery. These methods express leaf damage as a mean proportion and recovery as the proportion of new shoots from leaf axils. Seedling height, number of leaf pairs and number of branches were measured at four months before frosting began. The data for these five variables was analysed using ANOVA with appropriate transformations (Sokal \& Rohlf 1981). The two-tailed Student's t-test was used to test the significance of different levels of frost damage and height between species. A probability level of 0.05 was adopted for the rejection of null hypotheses.

\section{RESULTS}

There was a significant species by waterlogging by fertiliser application interaction for the three growth variables (tables 1, 2). The effect of waterlogging on the relative height growth of species varied with fertilisation. In the unfertilised pots, the order of species from that most to that least affected by waterlogging was $E$. gunnii, E. rubida, $E$. pauciflora, E. coccifera, E. rodwayi, E. ovata. In the fertilised pots the equivalent order was $E$. pauciflora, $E$. rubida, $E$. coccifera, E. rodwayi, E. gunnii, E. ovata. Waterlogging increased the height growth of E. ovata in fertilised pots, while only decreasing it marginally in unfertilised pots. In contrast, its upslope neighbour, E. rubida, attained less than $40 \%$ of its unwaterlogged heights in both fertilised and unfertilised pots, suffering proportionately more in the fertilised condition. Fertiliser application did not affect the reduction of height caused by waterlogging of $E$. rodwayi, which was to approximately $65 \%$ of the unwaterlogged plants. Its upslope neighbour, $E$. pauciflora, suffered more from waterlogging in the fertilised pots, with a reduction to $21 \%$ of its unwaterlogged height, than in the unfertilised pots, where the equivalent figure was $46 \%$. E. gunnii attained only $35 \%$ of its unwaterlogged height in unfertilised pots, while attaining $70 \%$ in fertilised pots. Its upslope neighbour, $E$. coccifera, was reduced in height by approximately half in both fertilised and unfertilised pots, with a slightly greater reduction in the former. Thus, all the species of the slopes suffered proportionately more from waterlogging in fertilised pots, while all the species of the flats showed the reverse pattern or no change. In the cases of E. ovata versus $E$. rubida and $E$. rodwayi versus $E$. pauciflora there was a significant difference $(\mathrm{P}<0.001)$ in height within the fertilised and waterlogged treatment, but not within the unfertilised and waterlogged treatment $(\mathrm{P}>0.05)$. In the case of $E$. gunnii versus $E$. coccifera, the significant difference pertained to the unfertilised and waterlogged treatment $(P<0.001)$, not the fertilised and waterlogged treatment $(P>0.05)$.

The number of leaves exhibited similar patterns of response to seedling height, except that $E$. pauciflora, the slopes species, performed marginally better in waterlogged, unfertilised conditions than E. rodwayi, and this latter species had a proportionately slightly greater reduction in growth in fertilised, waterlogged conditions than in unfertilised, waterlogged conditions (table 2).

Branching was rare in unfertilised pots, especially those that were waterlogged, although $E$. ovata increased its mean number of branches with waterlogging. In fertilised pots branching was more prolific, especially when the pots were not waterlogged, with $E$. ovata again being an exception by increasing its mean branch number with waterlogging (table 2). In the fertilised, waterlogged treatment, the three flats species maintained high numbers of branches, while branches were absent or rare on the seedlings of the slopes species (table 2 ).

Waterlogging significantly decreased frost damage and recovery, and fertiliser application increased them (table 1). There were no significant interactive effects (table 3 ). The order from the most frost-damaged to the least frostdamaged species was E. gunnii, E. ovata, E. rodwayi, E. coccifera, E. rubida, E. pauciflora (table 3). However, the order of species differed markedly between treatments (table 4). For example, E. gunnii was little damaged in the waterlogging-no fertiliser treatment, while being heavily damaged in all others (table 4). While the three species of the flats were all more damaged than the three species of the slopes, only the comparison between $E$. ovata and E. rubida was significant among the three pairs (table 3 ). E. rubida was also significantly less frost-damaged than E. rodwayi and E. gunnii, and E. pauciflora was significantly less damaged than E. ovata and E. gunnii (table 3). There was no significant species effect for recovery (table 1 ). There were no interactive effects for the damage and recovery variables (table 1).

\section{DISCUSSION}

The results of our experiment support relative resistance to waterlogging but not to frost, as a cause of the local distribution patterns of the three pairs of species, given that the species of the slopes, where frosts are less frequent and intense than on the flats (Fensham \& Kirkpatrick 1992), were less damaged by frost in an unhardened state than those of the flats. It is likely that major frost damage in the field occurs in the growing season (Davidson \& Reid 1987), as well as in the winter months. In this respect, it is interesting to note that the differences in frost resistance between $E$. rodwayi, E. gunnii and E. ovata became less apparent after hardening in other experiments similar to those reported herein (Kirkpatrick \& Gibson, in press), as did the differences reported by Davidson \& Reid (1987). In another experiment, with only mildly hardened seedlings and the same frosting procedures, Kirkpatrick \& Gibson (in press) found $E$. rodwayi to be significantly less damaged than $E$. ovata and $E$. gunnii, a result consistent with their reciprocal planting experiments. This result agrees with the order of resistance found in the present experiment, in which the faster growing seedlings sustained more damage than the slower growing seedlings, with Pearsons product moment correlations between arcsin damage and all of height, leaf number and branch number being significant at $P<0.001$. This result suggests that hardening through lack of nutrients and/or waterlogging can ameliorate the impacts of frosting. Hardening induced by waterlogging, in the absence of fertiliser application, reduced or reversed the contrast in 
TABLE 1

Results of the analysis of variance for the waterlogging and fertiliser application experiment with six eucalypt species

\begin{tabular}{lccccc}
\hline Treatment & Height $(\log )$ & Leaf no. $(\log )$ & Branches $(\log )$ & Damage $(\arcsin )$ & Recovery \\
\hline Species (S) & $* * *$ & $* * *$ & $* * *$ & NS \\
Waterlogging (W) & $* * *$ & $* * *$ & $* * *$ & $* * *$ & $*$ \\
Fertilizer (F) & $* * *$ & $* * *$ & $* * *$ & NS & NS \\
S X W & $* * *$ & $* * *$ & $* * *$ & NS \\
Sx F & $* * *$ & $* * *$ & NS & NS \\
W X F & NS & NS & $* * *$ & NS & NS \\
S W W F & $* * *$ & $* * *$ & & $* *$ \\
\hline
\end{tabular}

${ }^{* * *}=\mathrm{P}<0.001,{ }^{* *}=\mathrm{P}<0.01,{ }^{*}=\mathrm{P}<0.05, \mathrm{NS}=\mathrm{P}>0.05$

TABLE 2

Means and standard errors ( ) in the three growth variables for the six species in the fertiliser application and waterlogging treatments*

\begin{tabular}{lllll}
\hline Species & \multicolumn{5}{c}{ Seedling height $(\mathrm{cm})$} \\
& $\mathrm{F}-\mathrm{W}-$ & $\mathrm{F}-\mathrm{W}_{+}$ & $\mathrm{F}+\mathrm{W}-$ & $\mathrm{F}+\mathrm{W}_{+}$ \\
E. ovata & $10.3(0.9)$ & $8.0(0.8)$ & $23.1(1.5)$ & $26.4(1.6)$ \\
E. rubida & $16.1(1.8)$ & $6.5(0.7)$ & $32.2(2.1)$ & $9.2(1.0)$ \\
E. rodwayi & $7.1(1.1)$ & $4.6(0.6)$ & $26.7(1.2)$ & $17.3(1.7)$ \\
E. pauciflora & $7.2(0.7)$ & $3.3(0.3)$ & $22.3(2.3)$ & $4.6(0.3)$ \\
E. gunnii & $7.9(1.0)$ & $2.8(0.3)$ & $17.8(1.9)$ & $12.4(2.3)$ \\
E. coccifera & $13.1(1.6)$ & $6.6(0.7)$ & $19.3(1.6)$ & $8.6(1.7)$
\end{tabular}

\begin{tabular}{lllll} 
& $\mathrm{F}-\mathrm{W}-$ & $\mathrm{F}-\mathrm{W}+$ & $\mathrm{F}+\mathrm{W}-$ & $\mathrm{F}+\mathrm{W}+$ \\
E. ovata & $10.3(0.2)$ & $8.5(0.2)$ & $27.5(0.8)$ & $36.3(1.1)$ \\
E. rubida & $11.4(0.1)$ & $5.2(0.2)$ & $23.5(0.7)$ & $7.6(0.2)$ \\
E. rodwayi & $11.6(0.4)$ & $7.5(0.2)$ & $45.8(1.4)$ & $28.4(1.0)$ \\
E. pauciflora & $7.3(0.1)$ & $5.0(0.1)$ & $19.9(0.7)$ & $5.8(0.2)$ \\
E. gunnii & $13.5(0.4)$ & $5.3(0.2)$ & $41.6(1.8)$ & $32.4(1.8)$ \\
E. coccifera & $12.6(0.4)$ & $5.9(0.1)$ & $37.0(1.2)$ & $9.2(0.4)$ \\
& & & & \\
& & Number of branches & \\
E. ovata & $\mathrm{F}-\mathrm{W}-$ & $\mathrm{F}-\mathrm{W}+$ & $\mathrm{F}+\mathrm{W}-$ & $\mathrm{F}+\mathrm{W}+$ \\
E. rubida & $0.1(0.0)$ & $0.3(0.0)$ & $3.3(0.1)$ & $4.8(0.2)$ \\
E. rodwayi & $0.0(0.0)$ & $0.0(0.0)$ & $2.2(0.1)$ & $0.0(0.0)$ \\
E. pauciflora & $0.3(0.0)$ & $0.0(0.0)$ & $8.1(0.2)$ & $5.0(0.3)$ \\
E. gunnii & $0.0(0.0)$ & $0.0(0.0)$ & $2.3(0.1)$ & $0.0(0.0)$ \\
E. coccifera & $0.0(0.0)$ & $0.0(0.0)$ & $5.2(0.3)$ & $4.2(0.3)$ \\
\hline
\end{tabular}

${ }^{*} \mathrm{~F}_{+}=$fertilised, $\mathrm{F}_{-}=$fertilised, $\mathrm{W}_{+}=$waterlogged, $\mathrm{W}_{-}=$not waterlogged.

frost resistance between $E$. gunnii and $E$. coccifera, and $E$. rodwayi and $E$. pauciflora, while accentuating the difference between E. ovata and E. rubida (table 4). Thus, on the more frost-prone sites, there appears to be little difference in frost resistance between slopes and flats species in conditions that most closely relate to nature, whereas, on the least frostprone site, the slopes species is markedly more frost-resistant than the flats species in these conditions. These results further reinforce the conclusion that the relative distributions of the three pairs of species at the sites are not a product of relative frost resistance.

The failure of $E$. gunnii to resist waterlogging in nutrientpoor conditions and its success in nutrient-rich conditions, reflect a narrower edaphic range than the other two flats species. The success of $E$. ovata in resisting waterlogging is consistent with earlier work comparing this species with those of better-drained ground (Ladiges \& Kelso 1977, Guest 1982). The outstanding growth of E. ovata in the waterlogged and fertilised treatment (table 2) may relate to its possession of aerenchymatous roots at the start of the waterlogging treatment, thereby being able to take advantage of the accumulation of nutrients, in contrast to those species without such an initial state (N.J. Davidson, pers. comm.).

Davidson \& Reid (1987) reported that E. coccifera was more damaged than E. gunnii in a growing season frost of $-5.5^{\circ} \mathrm{C}$ at Snug Tier, Tasmania, whereas we found no significant difference in frost response. The inconsistency 
TABLE 3

Mean frost damage index ${ }^{\dagger}$ by species (FDI), with significant differences ${ }^{*}$

\begin{tabular}{lccccccc}
\hline Species & FDI & G & O & RO & C & RU & P \\
\hline E. gunnii (G) & 0.70 & & ns & ns & ns & $*$ & $* *$ \\
E. ovata (O) & 0.66 & ns & & $\mathrm{ns}$ & $\mathrm{ns}$ & $*$ & $* *$ \\
E. rodwayi (RO) & 0.66 & $\mathrm{~ns}$ & $\mathrm{~ns}$ & & $\mathrm{~ns}$ & $*$ & $\mathrm{~ns}$ \\
E. coccifera (C) & 0.54 & $\mathrm{~ns}$ & $\mathrm{~ns}$ & $\mathrm{~ns}$ & & $\mathrm{~ns}$ & $\mathrm{~ns}$ \\
E. rubida (RU) & 0.32 & $*$ & $*$ & $*$ & $\mathrm{~ns}$ & & $\mathrm{~ns}$ \\
E. pauciflora (P) & 0.28 & $* *$ & $* *$ & $\mathrm{~ns}$ & $\mathrm{~ns}$ & $\mathrm{~ns}$ & \\
\hline
\end{tabular}

${ }^{\dagger}$ Back-transformed from an arcsin transformation.

${ }^{\ddagger} \mathrm{ns}=\mathrm{P}<0.05,{ }^{*}=\mathrm{P}<0.05,{ }^{* *}=\mathrm{P}<0.01$, Two-tailed Students t-test.

TABLE 4

Mean frost damage index* by species and treatment ${ }^{\dagger}$

\begin{tabular}{lcccc}
\hline Species & $\mathrm{W}+\mathrm{F}+$ & $\mathrm{W}+\mathrm{F}-$ & $\mathrm{W}-\mathrm{F}+$ & $\mathrm{W}-\mathrm{F}-$ \\
\hline E. gunnii $(\mathrm{G})$ & 0.74 & 0.12 & 0.97 & 0.76 \\
E. ovata $(\mathrm{O})$ & 0.56 & 0.66 & 0.90 & 0.52 \\
E. rodwayi $(\mathrm{RO})$ & 0.72 & 0.19 & 0.43 & 0.71 \\
E. coccifera $(\mathrm{C})$ & 0.41 & 0.38 & 0.78 & 0.61 \\
E. rubida $(\mathrm{RU})$ & 0.26 & 0.02 & 0.74 & 0.55 \\
E. pauciflora $(\mathrm{P})$ & 0.21 & 0.10 & 0.61 & 0.29 \\
\hline
\end{tabular}

* Back-transformed from an arcsin transformation.

${ }^{\dagger} \mathrm{F}+=$ fertilised, $\mathrm{F}_{-}=$not fertilised, $\mathrm{W}_{+}=$waterlogged, $\mathrm{W}_{-}=$not waterlogged.

between our results and theirs may relate to the very different conditions that preceded and postdated frosting, or to the known geographic variation in frost resistance within both taxa (Potts I985, Gilfedder 1988).

\section{CONCLUSIONS}

The role of frost in vegetation patterning may not be great in Tasmania. Here frost-caused defoliation appears to be relatively common (Breton 1846, Calder 1850, Jackson 1973, Davidson \& Reid 1987, Gilfedder 1988, Cullen \& Kirkpatrick 1988, Fensham \& Kirkpatrick 1992), but there is only circumstantial evidence of the displacement of species from sites as a result of such defoliation, and this evidence relates to areas that were subject not only to severe frost but also to the early stages of a history of highly intense stockgrazing. In the cases of all the twentieth-century records of frost-induced defoliation, seedling regeneration or recovery through epicormic growth has maintained the damaged species on the site.

Our results cannot be taken as conclusive proof that relative waterlogging resistance is the prime cause of the boundaries between the flats and the slopes species. While the results do not invalidate this hypothesis, other mechanisms, such as relative ability to compete with a dense grass sward in the seedling stage and different interactions with the rest of the biota (Fensham \& Kirkpatrick 1992) could be important.

\section{ACKNOWLEDGEMENTS}

This study was supported by a grant from the Australian Research Council. We are grateful to Kristine Williams, Neil Davidson and Chris Harwood for their comments on an earlier draft of this paper.

\section{REFERENCES}

AsHTON, D.H., 1958: Ecology of Eucalyptus regnans F. Muell: the species and its frost resistance. Aust. J. Bot. 6: $154-$ 176.

BlaKe, T.J. \& REID, D.M., 1981: Ethylene, water relations and tolerance to waterlogging of three Eucalyptus species. Aust. J. Plant. Physiol. 8: 497-505.

BrETON, W.H., 1846: Excursion to the Western Range, Tasmania. Tasm. J. II: $121-140$.

CALDER, J.E., 1850: Some account of the country between Hamilton and Frenchman's Cap. Hobart Town Courier Saturday 21 September 1850.

COSTIN, A.B., 1954: A STUDY OF THE ECOSYSTEMS OF THE MONARO REGION OF NEW SOUTH WALES. Government Printer, Sydney.

Cullen, P.C. \& KIRKPATRICK, J.B., 1988: The ecology of Athrotaxis D. Don (Taxodiaceae) II. The distributions and ecological differentiation of $A$. cupressoides and A. selaginoides. Aust. J. Bot. 36: 561-573.

Davidson, N.J., 1985: Ecophysiological studies of factors determining the distribution of subalpine eucalypts at Snug Plains, southern Tasmania. Unpubl. PhD thesis, Univ. Tasm.

Davidson, N.J. \& Reid, J.B., 1987: The influence of hardening and waterlogging on the frost resistance of subalpine eucalypts. Aust. J. Bot. 35: 91-101.

FENSHAM, R.J. \& KirKPATRICK, J.B., 1992: The eucalypt forestgrassland/grassy woodland boundary in central Tasmania. Aust. J. Bot. 40: 123-138.

GILFEDDER, L., 1988: Factors influencing the maintenance of an inverted Eucalyptus coccifera treeline on the Mt. Wellington Plateau, Tasmania. Aust. J. Ecol. 13: 495503.

GUEST, S.A., 1982: The adaptive significance of seedling characteristics of Eucalyptus ovata Labill. and E. brookerana A.M. Gray. Unpubl. MSc thesis, Univ. Melbourne.

JACKSON, W.D., 1973: Vegetation of the Central Plateau. In Banks, M.R. (Ed.): THE LAKE COUNTRY OF TASMANIA. Royal Society of Tasmania, Hobart: 6185.

KirKPATRICK, J.B. \& Gibson, N., in press. Towards an explanation of the altitudinal distributions of three species of Eucalyptus in central Tasmania. Aust. J. Ecol.

Ladiges, P. \& Kelso, A., 1977: The comparative effects of waterlogging on two populations of Eucalyptus viminalis Labill. and one population of E. ovata Labill. Aust. J. Bot. 25: 159-169.

PARSONS, R.F., 1967: Effects of waterlogging and salinity on growth and distribution of three mallee species of Eucalyptus. Aust. J. Bot. 16: 101-108.

POTTS, B.M., 1985: Variation in the Eucalyptus E. gunnii-archeri complex. III. Reciprocal transplant trials. Aust. J. Bot. 33: 687-704.

SOKal, R.R. \& Rohlf, F.J., 1981: BIOMETRY. 2nd edn. Freeman, San Francisco.

Williams, K. J. \& POTTS, B.M., 1996: The natural distribution of Eucalyptus species in Tasmania. Tasforests 8: 39-165.

(accepted 5 May 1998) 